This is an Accepted Manuscript of an article published by Taylor \& Francis in Critical Studies on Terrorism on 21 March 2019, available online: https://www.tandfonline.com/doi/ full/10.1080/17539153.2019.1595922.

\title{
Restorative justice in the aftermath of politically-motivated violence:
}

\section{the Basque Experience}

\section{Author: Dr Margarita Zernova}

Affiliations: School of Education and Social Sciences, University of Hull, Hull, UK.

Correspondence details: $\quad$ margarita.zernova@hull.ac.uk

\author{
Margarita Zernova \\ School of Education and Social Sciences \\ University of Hull \\ Cottingham Rd., Hull \\ HU6 7RX, United Kingdom.
}

\begin{abstract}
An emerging body of literature discusses how restorative justice can contribute to the response to terrorism. This paper expresses concerns about the uncritical acceptance of many orthodox assumptions about terrorism inherent in the search for a 'restorative response' to terrorism. When restorative justice embraces the label 'terrorism' in what appears to be a politically neutral sense, rather than opening up a critical discussion of realities of political violence and the factors that had propelled it, it may form part of the efforts designed to inculcate 'truths' that help control political dissent. With its key aspiration being to restore a presumed healthy order disrupted by terrorist offences, restorative justice may be enlisted to help entrench social relations that led to the violence in the first place. The paper illustrates this danger by examining attempts to use restorative justice techniques by Spanish authorities in the aftermath of ETA or Euskadi Ta Askatasuna ('Basque Homeland and Freedom') violence. It is argued that rather than searching for a 'restorative response' to terrorism, a more adequate framework for restorative justice in the aftermath of politically motivated violence may be found within broader projects of reparation for historical injustices, remembering and political reconciliation.
\end{abstract}

Key words: ETA prisoners, restorative justice, reparation for historical injustices. 


\section{Introduction}

Restorative justice promises a radically different moral framework for responding to crime and other types of wrongdoing (Johnstone 2011; Pavlich 2005; Zehr 1990). It challenges 'conventional' criminal justice values and practices and aspires to offer a more humane alternative which, it is claimed, has a potential to heal victims, teach offenders valuable moral lessons, repair harm and restore communities (Wright 1996; Zernova 2007). Initially restorative justice was developed as a response to relatively non-serious offences, but it has gradually expanded its scope (Johnstone 2008, 2011, chapter 9).

Refusing to accept that terrorist attacks mark the limits of restorative justice, recently some proponents have embarked on a search for a 'restorative response' to terrorism, or speculations about how terrorism could be responded to in the spirit of restorative justice (Braithwaite 2016; Gavrielides 2016; Marshall 2007; Pemberton 2013; Salas 2015; Staiger 2010; VOMA 2001; Walgrave 2015). It is claimed that the social-ethical philosophy sustaining restorative justice has 'something special' to offer to counter-terrorism (Marshall 2007; Pereira 2017; Walgrave 2015). Restorative values may inspire a public policy very different to that grounded in fear, repression and revenge (Walgrave 2015). Advocates advance empirical evidence demonstrating that restorative justice can help prevent terrorism before the event (Braithwaite and Gohar 2014) and reflect on the possible contributions that restorative justice could make towards individual de-radicalization initiatives (Pereira 2017). It is suggested that restorative justice may 'help those who have inflicted terror to begin to rethink their own identities, to break free from the structures of violence that hitherto have dictated their worldview, and to learn to see reality differently’ (Marshall 2007, 388).

This paper expresses concerns about the direction in which some of the discussions in the area are developing. It argues that when restorative justice embraces the label 'terrorism' 
in what appears to be a politically neutral sense, rather than opening up a critical discussion of realities of political violence and the factors that had propelled it, it may form part of the efforts designed to inculcate values and 'truths' that help control political dissent and reproduce dominant power relations. With its key aspiration to restore a presumed healthy order disrupted by terrorist offences, restorative justice may be enlisted to maintain and entrench social relations which led to the violence in the first place.

The paper illustrates this danger by examining the attempts to use restorative justice techniques in the aftermath of ETA or Euskadi Ta Askatasuna ('Basque Homeland and Freedom') violence. It will be argued that in the Basque case, support for some restorative justice principles on the part of the Spanish authorities resulted in elements of restorative justice being employed to prevent potential challenges to the status quo and discredit the discourse of the political opponent. A different agenda will be proposed for how restorative justice could be - and to some extent already has been - mobilised in response to politically motivated violence. This approach places ETA violence in the context of an unresolved political conflict. The paper argues that rather than searching for a 'restorative response' to terrorism, as if 'terrorism' were an exceptional form of violence, a more adequate framework for restorative justice in the aftermath of politically motivated violence may be found within broader projects of reparation for historical injustices, remembering and political reconciliation. It will be suggested that, although the discussion in this paper revolves around the Basque context, the conclusions may have a wider application in societies emerging from a violent conflict and those that have to live with ongoing conflicts.

\section{Restorative Justice and Terrorism}

Restorative justice has been described as ‘subversive’ at its core, or 'an act of insurgency' (Sullivan and Tifft 2006, 5). It contests law's monopoly in securing justice and thus defies 
the state and those in power regarding how to respond to conflicts. Restorative justice prioritises meeting the victim's needs. It helps the offender understand the harm they have caused, come to accept the validity of shared social norms and assume liability for repairing the damage. It resists violent and pain-inflicting responses, stresses a constructive dialogue and aims to restore 'right relations' in the community.

An emerging body of literature explores possibilities of applying restorative justice principles, processes and approaches as part of the answer to terrorism. This literature claims that in the world where it is generally believed that inflicting terror is the only adequate way to respond to terror, restorative justice, with its challenge to dehumanising stereotypes and the emphasis on non-violent ways of community empowerment, could offer 'a small voice of protest’ (Marshall 2007, 388).

Advocates acknowledge numerous problems that arise when attempts are made to employ restorative justice in the context of terrorism (Marshall 2007, 381-2; Staiger 2010, 300-1; Walgrave 2015, 283-4; Pemberton 2014, 382). Yet, they proceed to identify the virtues of restorative justice which offer some hope that, even if it cannot offer a panacea, restorative justice could be at least 'one small fallible tool among many needed to redress terrorism’ (Marshall 2007, 383). Proponents refer to a still limited but growing body of evidence which, they argue, suggests that restorative encounters in the aftermath of terrorist offences can have a healing effect on their participants. Among examples are Patrick Magee and Jo Tuffnell’s meetings (Marshall 2007, 384-5; Staiger 2010, 316), victims/survivors from the different sides in the Northern Irish conflict engaging in a dialogue in the Glencree Centre for Reconciliation (White 2003), bereaved families in Israel/Palestine participating in dialogue with 'the other side’ (Staiger 2010, 324), a dialogue between Italian terrorists from the Red Brigades and families of their victims (Bertagna, Ceretti, and Mazzucato 2015), and 
restorative encounters between ex-ETA militants and victims of ETA violence in the Basque country (Pascual Rodríguez 2013; Varona 2013, 2014).

Based on this limited (and often anecdotal) evidence, proponents suggest that bringing hostile parties face-to-face may re-humanise and transform those involved. Victims may find answers to their questions and their pre-existing image of offenders as 'monsters' might begin to crumble (Ríos Martin 2013). Confronting offenders with the human costs of their actions may help them realise the full extent of the suffering they have caused (Carrasco Asenguinolaza 2013; Segovia Bernabé 2013). Such realisation in turn may have a reformative and reintegrative effect on them. It is argued that peaceful dialogue which is fundamental to restorative justice may offer the greatest antidote there is to terrorist violence (Marshall 2007, 388). Where direct encounters are not possible, restorative justice philosophy may inspire responses to terrorism which 'may yield more strength and more peace than purely repressive reactions in society’ (Walgrave 2015, 289).

The search for a 'restorative response' to terrorism appears to be based on several important assumptions. It seems to assume that terrorism is a unique form of violence which is of a 'qualitatively different nature' than other crime (Pemberton 2014, 375). It is further assumed that through encouraging victim awareness, empathy, redemption and reconciliation, restorative justice might provide radicalized individuals with 'a positive direction' (Pereira 2017, 22) and 'even may open a path towards the rehabilitation of the offenders' (Walgrave 2015, 289). Yet another assumption is that in the aftermath of terrorist attacks a restoration of prior social relationships within a pre-existing structural and normative framework is highly desirable. The shared commitment to communal norms is taken for granted, so, when the social norms are violated, reasserting them becomes a moral imperative. These assumptions will be revisited later in this article and their implications will be discussed. 


\section{Restorative Justice and Political Reconciliation}

Restorative justice offers a promising framework for thinking about justice in societies torn apart by gruesome violence and gross violations of human rights. It may help to satisfy victims’ demands for justice without alienating perpetrators (Johnstone 2008, 71). It may help to establish truth about past violations, promote peace and prevent future violence (Clamp 2014, 2016a; Lambourne 2016). Since the establishment of the South African Truth and Reconciliation Commission, restorative justice has been linked to a variety of initiatives and practices employed in response to violent conflicts (Aertsen et al. 2012; Llewellyn and Philpott 2014; Shirlow and McEvoy 2008).

Recently a number of leading proponents of restorative justice have acknowledged limitations of the emerging concepts of restorative justice in societies seeking political reconciliation (Braithwaite 2016; Bueno, Parmentier, and Weitekamp 2016; Clamp 2016a, 2016b; Cunneen 2016). They argue that currently there is a tendency to reduce causes and consequences of conflicts with deep historical roots to individual incidents. It is necessary to widen the 'lens' through which we view restorative justice, so as to equip it to deal with macro-political issues (Harbin and Llewellyn 2016; Zernova 2017).

Restorative justice is based on the belief that those who have been harmed require vindication and those who have inflicted harm should be held accountable. Adopting this formula leads to elevation of one group above the other. Restorative justice after mass violence should recognise that designations of 'victims' and 'perpetrators' are often muddled (Clamp 2014, 21-24, 2016a, 12, 2016b; Clamp and Doak 2012, 346-7). Restorative justice should move beyond the confines of current practices and acknowledge that all parties have suffered as a consequence of the conflict (Bueno, Parmentier, and Weitekamp 2016). 
Restorative justice should aim to transform conflict into peace (Clamp 2014, 32). It should provide opportunities for adversaries to engage with each other in a non-violent way on the points of differences. Such engagement may help humanise the 'other' and challenge pre-existing stereotypes and prejudices, making a new relationship possible (Doak 2016, 89).

At the same time, critics have expressed reservations about the potential of restorative responses to serve progressive ends following violent conflict and oppression. In the aftermath of atrocities, in an attempt to reconstruct the legal order and normalize social relations, disciplinary reparative techniques and re-education programmes designed to make individuals and communities internalize particular values may be employed. Victims and perpetrators may be encouraged to embrace 'technologies of self' that promote notions of 'forgiveness' and 'reconciliation', rather than what may be viewed as socially harmful discourses involving, for example, expressions of discontent towards the existing social order. By actively engaging individuals to reconstruct their self-identities and behavior, an effort may be made to 'reconcile' former conflicting parties in order to stabilize and protect an existing social order, rather than seek ways to correct the social conditions that caused violence to begin with (Woolford and Ratner 2008).

Nevertheless, it is suggested that restorative processes possess a communicative potential which might be usefully employed in the process of social transformation (Woolford and Ratner 2008). A genuine dialogue between the adversaries could facilitate the process of bottom-up 'truth-recovery’. This may be particularly valuable in situations where dominant political actors lack interest in creating formal mechanisms for dealing with past abuses (such as the Spanish government in the Basque case discussed in this paper). The bottom-up ‘truth-recovery’ could challenge what victims - especially victims of state violence - may see as a denial of truth (Lundy and McGovern 2008). Restorative justice could become part of the process of 'democratising the past' that attempts 'to give a 
democracy of equal recognition to the marginalized or victimized of the past' (Cairns 2003, 83). It could challenge 'official' representations of history which trivialize and justify mass cruelties and allow other narratives to emerge. Those narratives may gain public acceptance and help to disrupt hegemonic notions of justice (Cairns 2003; Woolford and Ratner 2008).

\section{The 'Basque Problem' and the Competing Narratives}

After half a century of its violent campaign against the Spanish state, in October 2011 ETA declared the definitive end of its armed activity ${ }^{\mathrm{i}}$. In April 2017 it concluded the process of disarmament, and, having apologised to all its victims, in May 2018 it announced its dissolution.

The end of ETA's campaign has produced competing narratives about what happened (Gabilondo 2011, 2018; Rubalcaba 2018). The dominant narrative promoted by successive Spanish governments, leading victims of ETA associations and the mainstream media in Spain denies the existence of a political conflict between Basque nationalists and the Spanish state and defines the so-called 'Basque problem' as 'terrorism'. This account tells the story of illegal violence by ETA, a terrorist organization, against the democratic Spanish state. In the end ETA was defeated: ‘terrorism’ lost and ‘democracy’ won (Alonso 2013; Domínquez 2012; Zarzalejos 2014). This narrative asserts that while ETA’s violence was illegitimate and unjustifiable, the state repression directed at the Nationalist Left was legitimate and necessary in defending the Spanish democracy (Alonso 2011). The only victims deserving recognition are victims of ETA violence. Attempts to recognise 'other' victims (that is, victims of violations of human rights by the Spanish state) are interpreted as efforts to justify ETA's crimes. Consistent with this view, Spanish legislation creates a hierarchy of victims, with ETA victims receiving the highest standard of protection and 'other' victims who suffered abuses of human rights by civil servants acting within their 
official duties receiving lower, or even an almost nonexistent standard of legal protection (Alvarez Berastegi 2017; Landa 2013).

The opposing narrative is put forward by the political movement to which ETA belonged - the Basque Nationalist Left. It affirms the existence of a political conflict in which Basque people have fought for their independence from Spain. ETA was a violent expression of that conflict and a reaction to decades or even centuries of Spanish aggression. On this view, Spain is not a democratic state. It occupies the Basque country, denying its people political and democratic rights. Although ETA has laid down its arms, from the perspective of the Nationalist Left, the political conflict continues and will be over once the Basque people obtain their right to self-determination. The end of ETA opened a new terrain for the Basque conflict - peace - with the political demands of the Nationalist Left being carried forward by the pro-independence coalition Euskal Herria Bildu ('Basque Country Unite').

Determined to deny the Nationalist Left even an indirect victory, so as to prevent ETA from claiming that its fundamental goals are on track, pursued by political means, the Spanish government insists on 'total victory' for the Spanish democratic state and defeat for ‘terrorists', while continuing its 'war on terrorism'.

\section{Restorative Justice at ETA's Endgame}

\section{ETA Prisoners and Individual Reinsertion}

As part of counter-terrorist policies, those serving prison sentences in relation to ETA crimes are subject to an exceptional penal regime and are treated differently from other prisoners (Landa 2012; Landa et el. 2014). Since the late 1980s they have been 'dispersed' throughout Spanish and French prisons, hundreds of kilometres away from their families ${ }^{\text {ii }}$. ETA 
prisoners are systematically refused exit permits. They are subjected to lengthy incommunicado detentions and systematic interception of communication. They are automatically classified into the so-called first 'grade' regime and are required to satisfy very stringent additional requirements to progress into second and then third 'grade'.

Successive Spanish governments made various attempts to 'break’ ETA from within by offering paths for individual reinsertion to its prisoners who were willing to distance themselves from ETA (Alonso 2011). Current conditions for individual reinsertion are provided by the 2003 reform of the penitentiary law. Under Article 72.6 of the penitentiary law, in order to be elevated into a third 'grade' regime of semi-liberty, prisoners charged with terrorist offences have to pay civil indemnities and expressly ask victims for forgiveness. They have to renounce their criminal past, reject violence and abandon both 'means' and 'ends’ of terrorism. They have to provide assurances that they have distanced themselves from the terrorist organisation and its 'environment'. Also, they have to actively collaborate with the authorities to help resolve crimes committed by the terrorist organisation and help identify, capture and prosecute those responsible for terrorist offences. The requirements that ETA prisoners apologise and pay economic compensation to victims, repent their wrongdoings and provide re-assurances that they will not repeat their crimes appear to be consistent with the restorative justice philosophy (Johnstone 2011; Wright 1996; Zehr 1990).

According to Etxerat (the association of family members of ETA prisoners), in January 2019, there were 258 people imprisoned due their activities in support of ETA or organizations linked to ETA (210 were in Spain, 47 in France and one in Portugal). Over 200 of them were classified as first 'grade' prisoners. It is estimated that had ETA prisoners taken advantage of the legal provisions specified in Article 72.6 of the Spanish penitentiary law, around 100 of them could have obtained penitentiary benefits in short term, and by 2020 half of all ETA prisoners could be released from prison (Aizpeolea 2016b). To the extent 
that the legal provisions in question embody some elements of restorative justice, restorative justice seems to offer a way out (Guenaga 2015). Yet, taking advantage of the legal provisions in question is something that the majority of ETA prisoners refuse to do.

Historically ETA prisoners denied the legitimacy of the Spanish criminal justice system. The refusal to cooperate with it was viewed as a form of resistance. Following the permanent ceasefire, the principle of 'resistance' has been replaced with the new aim of ‘emptying the prisons’ (Aizpeolea 2016a; Doria 2016). However, while accepting in principle that prisoners should be able to negotiate better conditions individually, they have rejected a possibility of participating in any initiatives that would require 'repentance' or 'betrayal' of comrades (Gorospe 2016a, 2016b). Yet, renunciation of their past and collaboration with the authorities to help resolve terrorist offences are the legal requirements for elevation into the third 'grade'. This creates a situation where the legal requirements for obtaining penitentiary benefits are virtually impossible for ETA prisoners to satisfy because denouncing their comrades and repenting their cause is unthinkable for them (Gorospe 2014; Val 2016).

\section{Restorative Justice and the 'Battle' of Narratives}

As ETA laid down its arms, the Nationalist Left has called for reconciliation and measures of transitional justice after decades of a violent conflict. While expressing its 'deep regret' for the suffering caused by the armed action of ETA and its own lack of sensitivity toward ETA's victims in the past, the Nationalist Left has called the Spanish and French states to acknowledge the suffering inflicted on Basque nationalists through repression and violations of human rights. It has called for the establishment of an international and politically impartial Truth Commission which should analyse the causes and consequences of the conflict, as well as the abuses perpetrated during it (Izquerda Abertzale 2012). 
However, the Spanish government has rejected the calls for transitional justice measures on the grounds that there was no conflict. The Basque context, it is argued, is not that of a political transition, rather it is a case of terrorism (Deia 2016; Efe 2015; El País 2013; Naiz 2015). Unlike transitional justice, there is a place for restorative justice which involves 'reparation of the injustice caused by the crime to the victims and reconstruction of the social fabric damaged by the crime according to normative expectations frustrated by the criminal behaviour' (ABC España 2013). In the Basque country, it is claimed, there are clear 'victims' and 'victimisers', and restorative justice requires that the 'victimisers' repair harm caused (El País 2013), so as to 'restore ... the situation prior to that produced through victimisation' (Deia 2016). There have been innumerable calls for ETA and the Nationalist Left to acknowledge the harm caused by ETA's violent campaign and express repentance. As part of that repentance, it is argued, ETA must reject the nationalist ideology which was the germ of violence and condemn their entire past (Alonso and Díaz Bada 2016; Reunión de Asociaciones y Fundaciones de Víctimas del Terrorismo 2010).

The Nationalist Left views restorative justice, with its requirements of repentance, as distorting the reality of what happened. It is argued that restorative justice grounded in the victim/offender dichotomy fails to acknowledge wrongdoings and suffering on both sides of the Basque conflict and puts all the blame on the Nationalist Left (Goirizelaia 2012). Nevertheless, the Nationalist Left apologised to victims of ETA (Izquierda Abertzale 2012; Munnarriz 2012, 200-201; Zaldua 2012). And, prior to its dissolution, ETA made an apology to all its victims and admitted its 'direct responsibility' for the suffering caused, as will be discussed in subsection 'Apologies and Commemorations' below.

In 2006 some twenty ETA prisoners complied with the legal requirements for individual reinsertion prescribed in Article 72.6 of the penitentiary law. They were moved to the Basque prison of Nanclares de Oca where they participated in an individual reinsertion 
project (Terradillos 2016; Unzueta Kareaga 2016; Ventura 2012). Some of these prisoners have requested an opportunity to meet their victims and ask for forgiveness. The Basque and the Central governments (both of which at the time were controlled by the socialist party) satisfied their request and established a victim-offender mediation programme (Pascual Rodríguez 2013; Varona 2013).

Both victims and offenders participating in the programme found the encounters helpful, and its promoters argued that the programme could contribute constructively to the peace process in the Basque country (Pascual Rodríguez 2013; Urkijo Azkarate and Gallizo Llamas 2013). Yet, the programme was criticised on the grounds that it failed to condemn the political ideology - radical nationalism - which justified terrorism (Alonso and Díaz Bada 2016). None of the offenders participating in the programme have collaborated with the criminal justice system to provide information concerning many unsolved crimes perpetrated by ETA. This, according to critics, put the sincerity of their repentance into question (Martínez 2012). When in December 2011 the conservative government of Mariano Rajoy came to power, it suspended the programme.

Although for different reasons, the Nationalist Left and the vast majority of ETA prisoners also rejected restorative encounters. The encounters were perceived as humiliating for ex-ETA militants (Varona 2014, 326). They were interpreted as a political tool designed to produce a split among ETA prisoners, with those taking part in the encounters receiving a preferential treatment (Morán 2012; Sainz 2012). 


\section{Restorative Justice in the Service of the 'Terrorism' Discourse}

\section{Restorative Justice as an Instrument of De-radicalisation}

In a political conflict, the treatment of prisoners mirrors the state's view of the conflict (McEvoy 2001). Denying the existence of a political conflict in the Basque country and the political status of ETA prisoners, the Spanish legal system defines ETA violence as a law and order problem and treats ETA prisoners as dangerous ones. Their actions are considered to be more heinous than those of 'ordinary' criminals, so, as noted above, they are subjected to an exceptional penal regime. ETA prisoners are managed either through attempts to rehabilitate them through 'showing them the error of their ways', or through containing and politically excluding those who are deemed incorrigible (Hogg 2012).

As explained earlier, elements of restorative justice have been embodied in the Spanish penitentiary law regulating the progression of those imprisoned for terrorist offences to the third 'grade', in particular, the principles of acceptance of responsibility for the harm caused, apology to victims, repentance, reparation of harm and assurances by wrongdoers that crime will not be repeated. Also, the requirements that offenders condemn not only their violent past but also the political ideology that sustained it, and collaborate with the criminal justice system to help identify other 'terrorists' have been added. These requirements are viewed as providing an objective evidence of repentance (Alonso and Bada 2016, 987).

The legislation in question draws on the right to re-education and social rehabilitation of prisoners embodied in the Spanish Constitution (Article 25.2). Using a Foucauldian approach, Hogg (2012) has argued that under the ethos of re-education and social rehabilitation the Spanish state has designed strategies to neutralise political dissent by trying to direct the 'deviants' to 'normality'. The measures designed to render individual prisoners politically docile form part of a counter-insurgency strategy directed at ETA as an 
organisation. They serve to break the solidarity of political prisoners by fragmenting the group both physically (through the policy of dispersal) and morally (through encouraging a split within the collective) in the effort to reinstate the State's hegemonic order.

Restorative justice in the aftermath of ETA violence has been conceptualised as an instrument of de-radicalisation (Alonso and Díaz Bada 2016). When framed that way, it necessitates the assimilation of dominant social values and the renunciation of the ‘contaminated ends’ (Alonso and Díaz Bada 2016, 997), that is, the political ideology in the name of which ETA practised violence. ETA prisoners are invited to reconstruct their behaviour and remake themselves as political subjects. The renunciation of their past and their political ideals would serve to protect the existing political system and silence the narrative of the Nationalist Left.

As explained in the section 'Restorative Justice and Terrorism' above, those seeking to develop a 'restorative response' to terrorism express hope about the contribution which restorative justice may make to reforming radicalised individuals. The case of ETA prisoners might hint at a hidden purpose behind employing restorative justice in such contexts.

\section{A Self-Fulfilling Prophecy}

Observing how each move by ETA and the Nationalist Left away from violence has been met with hostility, some commentators concluded that the Spanish government does not regard the demise of ETA as desirable (Elejabarrieta Dias 2015; Jones 2016; Woodworth 2014; Zulaika \& Murua 2017:7). ETA violence prevented broad alliances of Basque nationalists (many of whom rejected methods employed by ETA) and enabled successive Spanish governments to dismiss their demands. ETA has been compared to 'a small ulcer, which sometimes bleeds but doesn’t kill’ (Ansón, quoted in Whitfield 2014, 301). By contrast, 
Basque independence pursued by peaceful means is a 'cancer' which presents a lethal threat to the unity of Spain.

What is demanded of ETA prisoners is an ideological retraction. Unsurprisingly, most of them find meeting the legal requirements discussed above impossible to contemplate. As an international mediator who has been instrumental in the Basque peace process has put it,

[t]he words the Spanish government is asking Basque prisoners to say in order to end the exceptional measures used against them are deliberately designed to ensure the prisoners cannot say them. They're being asked to reject everything they’ve been involved in, their beliefs and their actions. And the prisoners are not prepared to do that.

(Currin, cited in Clancy 2015).

In the words of the former Spanish Interior Minister, the Spanish government will continue its anti-terrorist policies until it resolves 'all ETA crimes' and 'until the last member of ETA asks for forgiveness and repents what they have done' (Ormazabal 2018). That may imply an unending war. Far from being merely a mirror of events, discourse may create its own reality, and terrorism is a type of discourse that becomes a self-fulfilling prophecy (Zulaika 2009, 2018). Spanish government has a vested interest in promoting the 'terrorism' discourse that tells the story of senseless violence and serves to deny that ultimately ETA's goals were political in nature. The insistence that ETA prisoners repent their cause and collaborate with the criminal justice system provokes defiance and results in counter-terrorism perpetuating itself years after ETA had abandoned its armed campaign. 


\section{'Compulsory Compassion'}

The anti-terrorist legislation which, in exchange for penitentiary benefits, seeks to elicit in ETA prisoners repentance ignores the fact that the emotional states of repentance and compassion cannot be forced. Indeed, ‘[c]ompulsory compassion is an oxymoron’ (Acorn 2004, 137). To feel remorse, offenders need to accept the community’s judgments of their behaviour as reasonable. If they see the judgement as too harsh, they are likely to 'simply reject it and see themselves as victims of unjust condemnation' (Johnstone 2011, 77). This seems to be the case with ETA prisoners. Spain has granted a full amnesty to those who committed gross violations of human rights during the Franco dictatorship. Following the transition to democracy, it has also allowed those who tortured and mistreated ETA suspects and promoted state-sponsored terrorism against ETA to effectively escape punishment (Amnesty International 2007, 2009a; Cuadra Lasarte 2009; Gorospe 2017). Yet, it refuses any forgiveness to ETA prisoners.

ETA prisoners are required to apologise to their victims, however Spain has never apologised for the crimes committed against the Nationalist Left by the Franco regime, nor has it apologised for the widely documented violations of human rights committed by the state officials against those suspected of ETA terrorism under the democracy (Amnesty International 2007, 2009a, 2009b; Carmena et al. 2013; Whitfield 2014a, 125-8). This creates a climate that, far from encouraging ETA prisoners to express grief for the damage they have caused and seek opportunities to put things right, helps to entrench self-justifying attitudes and feelings of victimisation and unfairness.

Apology may be a useful tool: it has the power both to rehabilitate the individual and restore social harmony (Tavuchis 1991, 9). However, making apology a legal condition for the progression of those imprisoned for terrorist offences to a third 'grade' regime is unlikely 
to have that effect. The legal requirement of apology demands that 'freedom fighters' accept the victor's label as 'terrorists'. It imposes a simplistic distinction between the guilty 'perpetrators' and innocent 'victims' in a complex context characterised by multi-lateral violence and a disagreement among the participants about their identities and interpretations of the events. In doing so, it fails to establish the moral common ground which is necessary for the process of reconciliation to occur (Andrieu 2010). This legal requirement involves an attempt to impose a single 'truth' which is likely to be counter-productive and provoke competing 'truths' which will present powerful obstacles in the way of social reconciliation.

When calls for repentance and apology are unanswered, the emotional identification exclusively with innocent victims is reinforced and 'the agents of evil' are further driven 'outside the confines of humankind' (Todorov 2009, 461). This ensures a continuation of the counter-terrorism campaign for years to come.

\section{A 'Restorative Response' to Terrorism}

Political violence is a historically omnipresent phenomenon, yet describing it as ‘terrorism’ sets it apart from any other form of warfare (Douglass and Zulaika 1990; Zulaika and Douglass 1996, 6). The term 'terrorism' carries a demonising impact and produces fear and moral disgust against those labelled as ‘terrorists’ (Sluka 2008). It serves to deny the legitimacy of their political grievances and to prevent rational thought, discussion and consideration of underlying political causes. Defining particular acts of violence as 'terrorism' helps to justify state violence against 'terrorists', as well as morally questionable policies which otherwise the public would oppose (Jackson 2005, 2007). 
Many well-informed observers may be inclined to believe that the cause of Basque independence pursued by ETA was legitimate (even if they disagree with the methods ETA used to achieve it). However, confronting the Basque separatist movement, successive Spanish governments have re-branded their political opponents as 'terrorists'. That meant that the solution to the so-called 'Basque problem' required a vicious counter-terrorism campaign, as opposed to political concessions and conciliation-oriented responses.

As discussed at the beginning of this paper, some restorative justice advocates started a search for a 'restorative response' to terrorism. That effort seems to be based on the assumption that 'terrorism' is an ontologically stable phenomenon and a unique kind of violence. The existing power structures seem to be taken for granted and viewed in need of protection from ‘terrorism' (although through a more humane approach than that involved in the 'war on terror'). Such uncritical acceptance of many orthodox assumptions about terrorism expresses an underlying ideological bias. It fails to acknowledge the politics involved in naming individuals and groups as 'terrorist' and ignores the role of the state and its repressive apparatus in creating an environment in which terrorism is viewed as a legitimate tactic to some actors (Sluka 2008).

As the Basque case illustrates, the moment restorative justice accepts state-based accounts of 'terrorism', it takes a political stance which permits redefining political dissent as criminal actions of isolated individuals. The pre-suppositions that the morality of what happened is indisputable, and that 'the values attacked by terrorists must be reaffirmed with ... vigour' (Walgrave 2015, 289) disable the possibility of opening up a political debate about the meaning and underlying causes of terrorist violence. Within that framework, those opposed to the status quo are assumed to be the problem, 'without considering whether the status quo is part of the problem and transformation of both sides is necessary for its solution' (Gunning 2007, 372). 
An inspirer of the restorative justice movement Nils Christie relentlessly challenged restorative justice advocates to think critically about criminal justice concepts (Christie 1982, 74, 2004, 3). He argued, 'there are dangers in words', especially those close to criminal law, as they encourage us to think and act within that framework (Christie 2013, 18). This warning seems to have been ignored in the search for a 'restorative response' to terrorism.

Christie's advice for restorative justice proponents is to '...simply say: we work with conflicts' (2013, 19, also 1977). This terminology, he argues, is less open to abuse. Yet, the 'terrorism' discourse abhors the term 'conflict', as the Basque case demonstrates. When a conflict is defined away and the criminal law concept 'terrorism' is allowed to shape the debate, unintentionally restorative justice enlists itself in the service of criminal justice rationales and practices. The search for a 'restorative response' to terrorism becomes fundamentally entrenched in the logic and assumptions of criminal justice. The 'subversive' (Sullivan and Tifft 2006, 2) potential of restorative justice to defy the state and those in power regarding how to respond to conflicts is lost.

\section{A Different Agenda for Restorative Justice?}

\section{Restorative Justice and the 'Conflict' Narrative}

The Nationalist Left and most ETA prisoners have rejected restorative justice in favour of transitional justice measures (Varona 2013, 221, 2014, 326, 237). This rejection seems to be directed at a particular model based on a very narrow understanding of what restorative justice is and what it aims to achieve. Indeed, probably many proponents of restorative justice would question whether the measures embodied in the Spanish anti-terrorism legislation that have been discussed above have anything to do with restorative justice. Also, the presentation of restorative justice and transitional justice as completely separate concepts, which is promoted by both sides in the 'battle' of narratives described earlier is doubtful. 
The two concepts overlap. Restorative justice has been widely applied in transitional contexts (Clamp 2014), and conversely measures of transitional justice, such as truth commissions, reparations, official apologies and other forms of acknowledgement of wrongs, have been invoked in settled liberal democracies attempting to deal with their past (Cunneen 2006; Hayner 2011, 14-16).

Restorative justice is not necessarily inconsistent with the 'conflict' narrative of the Nationalist Left. This can be illustrated by the peacemaking approach embodying the spirit of restorative justice which has helped to stage ETA's permanent ceasefire, disarmament and dissolution. When the Spanish government refused to engage in any dialogue with, and facilitate an orderly end of, ETA, the Nationalist Left had to act unilaterally, invoking the international community as a witness. In October 2011 a group of peacemakers gathered at an international peace conference in San Sebastián to help bring to an end what they called 'the last armed confrontation in Europe'. They made an appeal asking ETA to declare the definitive cessation of all armed action, and ETA responded to that call promptly. The peacemakers also urged the Spanish and French governments to agree to talks with ETA and address 'the consequences of the conflict'. They called for dialogue, reconciliation, assistance to all victims, recognition of the harm caused and healing of personal and social wounds. International peacemakers similarly facilitated ETA’s disarmament and more recently dissolution after the Spanish government had refused to provide a 'way out' to ETA.

Importantly, these peacemaking efforts shaped the issue as a political conflict, with ETA being referred to as 'the last armed group on the continent'. The international peacemakers asked ETA to stop violence, while acknowledging that its struggle was political. This approach allowed ETA to conclude its 'historical cycle and function' with some sense of dignity: even though ETA did not achieve any of its political goals, it could claim that its goals were on track, pursued by peaceful means. This is something that could not be possible 
within the framework of the 'terrorism' narrative which insists on 'total victory' for the Spanish democracy and defeat for the 'terrorists'.

ETA used terrorism as a method. However, to define the 'Basque problem' exclusively in terms of terrorism is to mask the plurality of individual experiences and to conceal the legacy of human rights abuses on a massive scale. It may be possible to develop a vision of restorative justice that refuses to position itself as a servant of the dominant 'terrorism' narrative which tells only a part of the story. That approach would avoid final judgments about the morality of what happened, welcome debate and recognise that political reconciliation is best sought through dialogue and disagreement, rather than an imposition of a single state-sponsored 'truth' about the past.

As noted at the beginning of this paper (section 'Restorative Justice and Political Reconciliation'), some advocates of restorative justice have argued that in the aftermath of mass violence and political oppression restorative justice should adopt a more forwardlooking approach and aim to transform conflict into peace (Clamp 2014, 32). It should aspire to address not only violence between individuals, but also the structural conditions which have generated individual instances of violence (Clamp 2016a, 2016b; Cunneen 2016; Harbin and Llewellyn 2016; Woolford and Ratner 2008). Restorative justice should question the simplistic distinction between 'victims' and 'offenders' and acknowledge that in complex contexts following mass violence all parties have suffered in the course of the conflict (Bueno, Parmentier and Weitekamp 2016; Lundy and McGovern 2008).

Such way of conceptualising restorative justice fits well with the Nationalist Left's calls for political reconciliation, recognition of suffering on all sides of the conflict, analysing the causes and consequences of the conflict and uncovering the abuses perpetrated during it (see subsection 'Restorative Justice and the 'Battle' of Narratives' above). A model of restorative justice which addresses all violations of people and relationships, irrespective of 
who the perpetrator is, would view in a similar light violence practised by ETA and violence exercised by Spanish state agents who killed, maltreated, tortured and engaged in statesponsored terrorism as part of repression of the Nationalist Left. Recognition of suffering of victims of state violence may help reduce the acute sense of injustice felt by the Nationalist Left and advance the project of social reconciliation.

\section{Restorative Justice and Reparations for Historical Injustices}

An approach which views ETA violence within the context of a political conflict involving multi-lateral violence and unresolved grievances may result in diverse initiatives which may not match 'traditional' models of restorative justice. Yet, they pursue restorative justice’s project of reparation through 'historical inquiry, dialogue, and voice of those concerned or affected, and inviting active engagement in the present with the past' (Walker 2006:389). Such practices could be located within the paradigm of reparations for historical wrongs (Torpey 2003) and include efforts at truth finding, reconciliation, apologies and commemorations. Some Basque illustrations of such work will be provided below.

\section{'Democratising the Past'}

As has been mentioned earlier, the Nationalist Left has requested the establishment of a Truth Commission which would analyse the causes and consequences of the conflict and violations which took place as part of it (Izquierda Abertzale 2012). However, the Spanish government has not satisfied such requests (as explained above, it fervently denies its part in the multilateral violence, justifying the state repression of the Nationalist Left as legitimate in defending the Spanish democracy against ETA terrorism). In this context, a wide range of less formal projects aiming at truth-seeking have been launched in the Basque country (Aldaz 2012; Bengoetxea 2013; Etxeberria, Beristain, and Pego 2016; Gómez 2015; Sola 2012b; Whitfield 2014, 280-2). Some of these initiatives concerned victims of abuses of the state 
power, such as foundations Euskal Memoria which dedicates its work to recuperation and reconstruction of the 'stolen' memory of the Nationalist Left, and Egiari Zor ('a debt of truth') created by relatives of victims of repression by the Spanish and French states to defend victims of the state violence (Aldaz 2012). In June 2012 the Basque Parliament approved a decree addressing victims of torture and police violence committed between 1960 and 1978 which for the first time recognized such victims formally.

All these developments could be viewed within the framework of restorative justice. They contribute to efforts of reparation of historical injustices by acknowledging suffering of long-neglected victims of state violence and allowing 'voices from below' (Lundy and McGovern 2008, 265) to be heard. These voices could form part of the process of 'democratising the past' (Cairns 2003, 83) which involves giving recognition to those who had been previously silenced by the narrative promoted by the powerful actors. Such recognition in itself provides a component of justice (Cairns 2003, 84).

\section{Promoting Co-existence}

Various initiatives aiming at promoting co-existence and social reconciliation fit well with the restorative justice philosophy. Some of them were supported by the Basque government (such as the Plan for Peace and Co-existence) and the previous central socialist government of Zapatero (such as the victim-offender mediation in the Nanclares prison mentioned above). Others were initiatives of civil society organizations. One notable example is the 'Social Forum’ created by Lokarri, Red ciudadana por la paz (Citizens’ Network for Peace), Bake Bidea (a peace organisation of the French Basque Country) and other networks and groups working on the peace process, with support of international NGOs and experts. The Social Forum sought to promote the peace process by strengthening the role of Basque society in it and urging state institutions and political parties to find solutions to issues of disarmament, 
reintegration of ETA prisoners, human rights, and dealing with the past, memory and reconciliation (Rios 2014). Another remarkable example is the Glencree Initiative which brought together victims from all sides of the conflict and engaged them in dialogue (Rivas 2012; Sola 2012a). Victims of various forms of violence (together with ex-ETA combatants and peace activists) also took part in multiple conferences, seminars and roundtable discussions promoting peace and co-existence.

In Errenteria and Azpeitia - Basque towns where many lives were lost on both sides of the conflict - initiatives were created which united those subscribing to opposing political views and generated discussions and debates (Aizpuru 2016; Burgueño 2013; eitb.eus 2016; Eizmendi 2012; Hedgecoe 2014; Sainz 2016; Sola 2015). The participants shared their experiences of the conflict and explored possibilities of future co-existence. In accordance with restorative justice principles, a mechanism has been provided that offered opportunities for people in the midst of a conflict to 'explain and humanize themselves to one another' (Bush and Folger 1994, 20). Where divisions within social groups are deep, such initiatives bridge 'the gulf of historical hatred to resume a dialogue that will allow [the hitherto opposed parties] to live under some overarching rules of comity and coexistence' (Maier 2003, 298). By inviting public dialogue, initiatives of this kind enable 'untangling' thoughts, emotions and motivations and help the participants understand better the source of the conflict (Walker 2006, 391).

\section{Apologies and Commemorations}

Prior to its dissolution ETA apologised to all its victims. It acknowledged the harm it has caused and expressed a commitment to overcome the consequences of the conflict, 'so that such events never happen again in the future’. In its apology ETA talked about acknowledging and respecting suffering of political opponents; accepting responsibilities; the 
need for reconciliation in the Basque country; truth-finding, curing wounds, peace-building and 'finding a political solution to the conflict'. This apology is consistent with restorative justice values, while maintaining the 'conflict' narrative ${ }^{\mathrm{iii}}$. Unlike the individual apologies required from ETA prisoners by the Spanish legislation discussed above which defines ETA’s violence as crimes of isolated individuals, ETA’s apology was collective, underscoring that ETA acted as an organisation pursuing political goals.

The collective apology in some cases has been supplemented with individual apologies. Some ex-ETA militants asked their victims for forgiveness (Carrasco Asenguinolaza 2013; Pascual Rodrígues 2013). Some of them took part in commemoration ceremonies dedicated to ETA victims (Gastaca 2013; Iglesias 2014; San Miguel 2016; Segovia 2013; Terradillos 2016). The participation of ETA in such events and placing bouquets of flowers at feet of monuments bearing names of ETA victims may be interpreted as examples of non-verbal apologies (Lazare 2004, 37-8). They signify the acknowledgement of an offence, expression of remorse, recognition of shared values and assurances that the offence will not be repeated. The permission of families of ETA victims to allow ETA ex-combatants to participate in commemoration ceremonies might signify that apology is accepted. Thus the process of building trust between ex-combatants and their victims begins. Practices of this nature do not demand that people who were willing to kill and die for their cause say that their actions were wrong, reject their political ideals and condemn half a century of sacrifice by thousands of Basque nationalists. At the same time, they enable ex-militants to express regret to their victims for the pain they have caused and reassure them that they will not do the same again. 


\section{Conclusion}

Today ETA violence belongs to the past. ETA has observed its ceasefire, disarmed, apologised to all its victims and dissolved itself. Yet, the Basque society remains deeply divided in its political views and goals, as well as interpretations of what happened in the last half a century and why. Despite the efforts of successive Spanish governments to deny the existence of a political conflict and enforce the narrative of 'terrorism', a sizable minority of Basques refuses to accept what they see as a narrative of the oppressor and puts forward a counter-narrative of Basque patriots fighting for their freedom. The war continues by other means.

In the 'battle' of narratives which unfolded at ETA's endgame, elements of restorative justice have been employed to reinforce the narrative of 'terrorism' which defines ETA violence within the framework of criminal law. While that narrative may have much truth to it, it puts forward a particular moral perspective on the past in a scenario where there is no moral consensus about the events and their meaning. Restorative justice techniques have been invoked as a condition for the improvement of prisoners' situation in an attempt to de-radicalise ETA prisoners and bring them to 'normality' (Hogg 2012). However, the requirements of repentance are viewed by most ETA prisoners as an affront to their dignity. Far from producing remorse, they lead to resentment and defiance. Restorative justice has been interpreted as an instrument designed to produce a split among ETA prisoners and rejected by majority of prisoners and the Nationalist Left.

This paper has argued that this rejection may have led to missed opportunities. Ideas of the scholars advancing a more radical model of restorative justice in the aftermath of atrocities are consistent with the proposals of the Nationalist Left and could offer them a theoretical basis. A model of restorative justice which recognises the existence of a political 
conflict and is placed within a broader project of repairing historical injustices, remembering and political reconciliation could be developed. That model may have potential to become an instrument of resistance to the dominant 'terrorism' narrative which, through imposing a single version of history, hinders the project of political reconciliation. Some steps in this direction have been already taken, for example, a peacemaking approach employing restorative justice principles and techniques has helped to facilitate successfully ETA's permanent ceasefire and dissolution. Other examples include initiatives aiming at truthfinding, efforts promoting co-existence, commemoration events, apologies and assurances of non-repetition.

Although this paper focused on the Basque country, its conclusions may have wider applications. The Basque case is a warning that in the aftermath of mass violence and violations of human rights, techniques of restorative justice may be utilised by dominant political actors in attempts to make individuals and groups internalise particular values (such as repentance and reparation), so as to discourage discourses viewed as undesirable by those in power (in particular, the discourses that question the existing political order). Restorative justice, with its potential for consolidating and strengthening normative standards (Bottoms 2003, 87) and its dedication to restoration of pre-existing relationships, may be usefully employed by the ruling elite with a view to neutralise political dissent and protect the existing political system.

In the Basque case it is easy to see that whether one defines political violence as ‘terrorism' or a legitimate act of war is a large part of the conflict. So, another lesson that emerges concerns the search for a 'restorative response' to terrorism. That search promises an approach that challenges current revengeful and punitive policies. Yet, simultaneously it seems to replicate commonly held beliefs about terrorism, singling it out as a unique form of violence and assuming that terrorism is an ontologically stable phenomenon. Definitions of 
‘terrorism’ are outcomes of political struggles, rather than an objective reality (Zulaika 2009, 18). Ignoring the politics involved in naming individuals and groups as 'terrorist' and accepting such labels without questioning in itself involves political choices in support of the existing political order. Such acceptance hardly advances the project of political reconciliation, as it insists on a common narrative 'in which the freedom fighter ought to assume his proper description as terrorist' (Christodoulidis 2000, 195) and express remorse. Instead of contrition, it produces defiance.

At the same time, the Basque case offers some illustrations of how, when dealing with historical controversies, restorative justice may contribute to the broad field of mending past wrongs, remembering and political reconciliation (Todorov 2009; Torpey 2003; Maier 2003; Walker 2006). New possibilities arise when in the aftermath of political violence, instead of grounding restorative justice in concepts and assumptions of criminal justice, it is recognized that the paradigm of criminal justice is ill-suited in the face of an unresolved political conflict. Rather than assuming a moral consensus, a more fruitful approach could be to think in terms of a process of contention which allows competing 'truths' to emerge and stories that previously had been silenced by hegemonic narratives to be told, so that unredressed injustices are acknowledged, suffering of living victims is recognised and the dead are commemorated. Restorative justice, then, could provide a framework for incremental work of reparation of historical injustices and seeking a common ground where one exists, and, where it does not, enabling participants to gain a better understanding of the issues which divide them, so that they could agree to live peacefully side by side with disagreements. 


\section{References:}

ABC España. 2013. “Un juez pide «Justicia restaurativa» para víctimas de la «violencia política»”. October 3. http://www.abc.es/espana/20131003/abci-ibarra-violencia-politica201310022123.html

Acorn, A. 2004. Compulsory Compassion: A Critique of Restorative Justice. Vancouver: UBC Press.

Aertsen, I., J. Arsovska, H.-C.Rohne, M. Valiñas, and K.Vanspauwen, eds. 2012. Restoring Justice after Large-Scale Violent Conflicts. Kosovo, DR Congo and the Israeli-Palestinian Case. Oxon: Routledge.

Aizpeolea, L.R. 2016a. "Más vale tarde”. El País, December 27. https://politica.elpais.com/politica/2016/12/27/actualidad/1482859259_283790.html

Aizpeolea, L.R. 2016b. “Sortu redobla la presión sobre los presos etarras para que asuman la legalidad penitenciaria”. El País, April 18.

https://politica.elpais.com/politica/2016/04/17/actualidad/1460908645_228516.html

Aizpuru, E. 2016. “El Foro por la Convivencia finaliza su andadura tras dos años y medio”. El Diario Vasco, December 3. http://www.diariovasco.com/costa-urola/azpeitia/201612/03/foro-convivenciafinaliza-andadura-20161203005644-v.html

Aldaz, A. 2012. “Nace la fundación Egiari zor para defender a las víctimas de «la violencia de los Estados»”. Diario Vasco, April 22. http://www.diariovasco.com/20120422/masactualidad/nace-fundacion-egiari-para-201204221806.html 
Alonso, R. 2011. "Why Do Terrorists Stop? Analyzing Why ETA Members Abandon or Continue with Terrorism”. Studies in Conflict and Terrorism 34(9): 696-716.

Alonso, R. 2013. “The Madrid Bombings and Negotiations with ETA: A Case Study of the Impact of Terrorism on Spanish Politics”. Terrorism and Political Violence 25(1): 113-136.

Alonso, R., and J. Díaz Bada. 2016. “What Role Have Former ETA Terrorists Played in Counterterrorism and Counterradicalization Initiatives in Spain”. Studies in Conflict and Terrorism 39(11): 982-1006.

Alvarez Berastegi, A. 2017. “Transitional Justice in Settled Democracies: Northern Ireland and the Basque Country in Comparative Perspective”. Critical Studies on Terrorism 10(3): $542-561$.

Amnesty International. 2007. España: sal en la herida. La impunidad efectiva de agentes de policía en casos de tortura y otros malos tratos.

https://www.es.amnesty.org/uploads/media/Sal_en_la_herida.pdf

Amnesty International. 2009a. España: sal en la herida. Impunidad policial dos años después. http://www.nodo50.org/ala/spip/IMG/pdf_Espana._Sal_en_la_herida_-

_Impunidad_policial_dos_aos_de_spues_.pdf

Amnesty International. 2009b. España: salir de las sombras. Es hora de poner fin a la detención en régimen de incomunicación.

https://www.es.amnesty.org/uploads/media/Salir_de_las_sombras.pdf

Andrieu, K. 2010. “Transitional Justice: A New Discipline in Human Rights”. Online Encyclopedia of Mass Violence. http://www.sciencespo.fr/mass-violence-war-massacreresistance/en/document/transitional-justice-new-discipline-human-rights-0\#title4 
Bengoetxea, J. 2013. “Transitional Justice versus Traditional Justice: the Basque case”. Journal of Ethnopolitics and Minority Issues in Europe 12(2): 30-58.

Bertagna, G., A. Ceretti, and C. Mazzucato. 2015. Il libro dell'incontro. Vittime e responsabili della lotta armata a confronto. Milan: Il Saggiatore.

Bottoms, A. 2003. “Some Sociological Reflections on Restorative Justice”. In Restorative Justice: Competing or Reconcilable Paradigms?, edited by A. Von Hirsch, J.V. Roberts, A. Bottoms, K. Roach and M. Schiff, 79-113. Oxford: Hart Publishing.

Braithwaite, J. 2016. Understanding Terrorism through Restorative Justice. http://johnbraithwaite.com/2016/11/15/understanding-terrorism-through-restorative-justice/

Braithwaite, J. 2016. “Learning to Scale up Restorative Justice”. In Restorative Justice in Transitional Settings, edited by K. Clamp, 173-189. London: Routledge.

Braithwaite, J., and A. Gohar. 2014. "Restorative Justice, Policing and Insurgency”. Law and Society Review 48(3): 531-561.

Bueno, I., S. Parmentier, and E. Weitekamp. 2016. "Exploring restorative justice in situations of political violence: the case of Colombia”. In Restorative Justice in Transitional Settings, edited by K. Clamp, 37-55. London: Routledge.

Bush, R. and J. Folger. 1994. The Promise of Mediation: Responding to Conflict through Empowerment and Recognition. San Francisco: Jossey-Bass.

Burgueño, A. 2013. “Rentería, de la leyenda negra a la búsqueda de la convivencia”. El País, February 3.

http://ccaa.elpais.com/ccaa/2013/02/03/paisvasco/1359893458_766881.html

Cairns, A. 2003. “Coming to Terms with the Past”. In Politics and the Past, edited by J. Torpey, 63-90. Oxford: Rowman and Littlefield Publishers. 
Carmena, M., J.M. Landa, R.Múgica, and J.M.Uriarte. 2013. Informe-base de vulneraciones de derechos humanos en el caso vasco (1969-2013). Vitoria-Gasteiz: Govierno Vasco.

Carrasco Asenguinolaza, L.M. 2013. “Aquella mañana me disponía a pedir perdón por un crimen imperdonable. Mi experiencia personal como ex-miembro de ETA ante los encuentros restaurativos”. In Los ojos del otro. Encuentros restaurativos entre victimas y ex-miembros de ETA, edited by E. Pascual Rodríguez, 277-280. Santander: Sal Terrae.

Christie, N. 1977. “Conflicts as a Property”. British Journal of Criminology 17(1): 1-15.

Christie, N. 1982. Limits to Pain. Oxford: Martin Robertson.

Christie, N. 2004. A Suitable Amount of Crime. London: Routledge.

Christie, N. 2013. “Words on words”. Restorative Justice. An International Journal 1(1): 1519.

Christodoulidis, E.A. 2000. “Truth and Reconciliation’ at Risks”. Social and Legal Studies 9(2): 179-204.

Clamp, K. 2014. Restorative Justice in Transition. London and NY: Routledge

Clamp, K. 2016a. "Restorative Justice as a Contested Response to Conflict and the Challenge of the Transitional Context: an Introduction”. In Restorative Justice in Transitional Settings, edited by K. Clamp, 1-15. London: Routledge.

Clamp, K. 2016b. “Towards a Transformative Vision of Restorative Justice as a Response to Mass Victimisation: Some Concluding Thoughts”. In Restorative Justice in Transitional Settings, edited by K. Clamp, 211-220. London: Routledge.

Clamp, K. and J. Doak. 2012. "More than Words: Restorative Justice Concepts in Transitional Justice Settings”. International Criminal Law Review 12(3): 339-360. 
Cuadra Lasarte, S. 2009. “¡Vivan Galindo, Vera, Barrionuevo, Amedo.... ¡Vivan!” Gara, August 28. http://gara.naiz.eus/paperezkoa/20090828/153825/es/

Cunneen, C. 2006. “Exploring the Relationship between Reparations, the Gross Violation of Human Rights, and Restorative justice”. In Handbook of Restorative Justice, edited by D. Sullivan, and L. Tifft, 355-368. London: Routledge.

Cunneen, C. 2016. “When Does Transitional Justice Begin and End? Colonised Peoples, Liberal Democracies and Restorative Justice”. In Restorative Justice in Transitional Settings, edited by K. Clamp, 190-210. London: Routledge.

Deia. 2016. “Ibarra rechaza la justicia transicional para ETA”. June 11. http://www.deia.com/2016/06/11/politica/estado/ibarra-rechaza-la-justicia-transicional-paraeta

Doak, J. 2016. "Stalking the State: the State as a Stakeholder in Post-conflict Restorative Justice”. In Restorative Justice in Transitional Settings, edited by K. Clamp, 74-94. London: Routledge.

Domínguez, F. 2012. La Agonía de ETA. Una investigación inédita sobre los últimos días de la banda. Madrid: La esfera de los libros.

Doria, J. 2016. “Sortu plantea adecuar al colectivo de presos al «nuevo tiempo político»”. El país, January 13.

https://politica.elpais.com/politica/2016/01/13/actualidad/1452696204_733510.html

Douglass, W., and J. Zulaika. 1990. “On the Interpretation of Terrorist Violence: ETA and the Basque Political Process”. Comparative Studies in Society and History 32(2): 238-257. 
Efe. 2015. "Fernández Díaz: No va a haber justicia transicional con ETA sino la normal”. September 30. https://www.efe.com/efe/espana/politica/fernandez-diaz-no-va-a-haberjusticia-transicional-con-eta-sino-la-normal/10002-2726031

Eitb.eus. 2016. Errenteria, sede de una experiencia 'real' de convivencia política. April 4. https://www.eitb.eus/es/noticias/politica/detalle/4027216/presentacion-publica-forodialogoerrenteria/

Eizmendi, M. 2012. Mirándose a los ojos con el objetivo de acercase al dolor ajeno. Naiz, February 4. http://gara.naiz.eus/paperezkoa/20130204/386191/es/Mirandose-ojos-objetivo$\underline{\text { acercasedolor-ajeno }}$

Elejabarrieta Diaz, G. 2015. “From Freedom Fighters to Terrorists and Back Again”. In Researching Terrorism, Peace and Conflict Studies, edited by I. Tellidi, and H.Toros,146164. London: Routledge.

El País. 2013. “Subijana descarta la aplicación de una justicia transicional en el caso vasco”. El País, November 7. https://elpais.com/ccaa/2013/11/07/paisvasco/1383827977_332581.html Etxeberria, F., C.M. Beristain, and L.Pego. 2016. Proyecto de investigación de la tortura en el País Vasco (1960-2013). https://ep00.epimg.net/descargables/2016/06/27/1ac4472e41f193bf24a08a676f7ab765.pdf Gabilondo, I. 2011. “Hay que ganar a ETA la batalla del relato”. El País, September 6. https://politica.elpais.com/politica/2011/09/06/videos/1315288476_398064.html

Gabilondo, I. 2018. “La disolución de ETA. La banda debió retirarse en silencio”. El País, May 3. https://elpais.com/elpais/2018/05/03/la_voz_de_inaki/1525332031_577356.html 
Gastaca, J.M. 2013. “La exetarra Gisasola abraza a la viuda de un ‘ertzaina’ asesinado”. El País, November 22.

http://ccaa.elpais.com/ccaa/2013/11/22/paisvasco/1385120100_118639.html

Gavrielides, T. 2016. “The Terrorist within: from a Restorative Lens”, Special International Issue on Terrorism. http://yeip.org/wp-content/uploads/2017/05/The-Terrorist-Within-From$\underline{\text { A-Restorative-Lens.pdf }}$

Gómez, V. 2015. Deconstruir la memoria para forjar la paz. El País, December 21. https://elpais.com/ccaa/2015/12/21/paisvasco/1450725648_704971.html

Goirizelaia, J. 2012. “Justicia para convivencia”. In Justicia para la convivencia. Los puentes de Deusto, edited by Forum de Deusto, 165-170. Bilbao: Universidad de Deusto.

Gorospe , P. 2014. “Los ex reclusos de la banda terrorista se suman a la política”. El País, January 21. https://politica.elpais.com/politica/2014/01/04/actualidad/1388831908_513647.html

Gorospe, P. 2016a. Los presos de ETA aseguran que “ni se arrepentirán ni delatarán”. El País, February 9. https://politica.elpais.com/politica/2016/02/09/actualidad/1455050748_665132.html

Gorospe P. 2016b. El colectivo de presos de ETA acepta permisos individuales pero sin arrepentirse. El Pais, December 27. https://politica.elpais.com/politica/2016/12/27/actualidad/1482826510_448607.html

Gorospe, P. 2017. El informe oficial sobre la tortura cita 336 casos sin condena contra la Ertzaintza. El País, December 18. https://elpais.com/ccaa/2017/12/18/paisvasco/1513614504_114013.html 
Guenaga, A. 2015. Los presos de ETA, en su laberinto. El diario.es, April 4.

http://www.eldiario.es/norte/euskadi/presos-ETA-laberinto-Vigilancia_Penitenciaria-

Barricada_0_373762648.html

Gunning, J. 2007. “A Case for Critical Terrorism Studies”, Government and Opposition 43(3): 363-393.

Harbin, A., and J. Llewellyn. 2016. "Restorative Justice in Transitions: the Problem of 'the Community’ and Collective Responsibility”. In Restorative Justice in Transitional Settings, edited by K. Clamp, 133-151. London: Routledge.

Hayner, P. 2011. Unspeakable Truths. New York and London: Routledge.

Hedgecoe, G. 2014. "Political Pressure Stops Spain from Putting Basque Conflict behind it”. The Irish Times, August 15. http://www.irishtimes.com/news/world/europe/politicalpressure-stops-spain-from-puttingbasque-conflict-behind-it-1.1897239

Hogg, A. 2012. “Directing Dissent: Governing Political Dissidence in Spanish Prisons”. Oñati Socio-Legal Series 2(1): 1-28.

Iglesias, L. 2014. “Un arrepentido de ETA honra a su victima”. El Mundo, July 30. http://www.elmundo.es/pais-vasco/2014/07/30/53d89660ca47419d458b456c.html

Izquierda Abertzale. 2012. Viento de solución.

http://www.berria.eus/dokumentuak/dokumentua885.pdf

Jackson, R. 2005. Writing the War on Terrorism: Language, Politics and Counterterrorism. Manchester: Manchester University Press.

Jackson, R. 2007. "Playing the Politics of Fear: Writing the Terrorism Threat in the War on Terrorism”. In Playing Politics with Terrorism: A User's Guide edited by G. Kassimeris, 176-202. New York: Columbia University Press. 
Johnstone, G. 2008. “ The Agendas of the Restorative Justice Movement”. In Restorative Justice: from Theory to Practice, edited by H. Ventura Miller, 59-79. Bingley: JAI Press. Johnstone, G. 2011. Restorative Justice. Ideas, values, debates. London and New York: Routledge.

Jones, S. 2016. “Free after Six Years, but What Now for Basque Separatist Leader Arnaldo Otegi?” The Guardian, April 24. https://www.theguardian.com/world/2016/apr/29/freeafter-six-years-but-what-now-for-arnaldo-otegi

Lambourne, W. 2016. "Restorative Justice and Reconciliation: the Missing Link in Transitional Justice”. In Restorative Justice in Transitional Settings, edited by K.Clamp, 5673. London and New York: Routledge.

Landa, J.-M. 2012. “Presos: exigencias éticas y jurídicas. Justicia para convivencia”. In Justicia para la convivencia. Los puentes de Deusto, edited by Deusto Forum, 193-202. Bilbao: Universidad de Deusto.

Landa, J.-M. 2013. "Human Rights and Politically-motivated Violence in the Basque country.” Journal of Ethnopolitics and minority Issues in Europe. 12(2): 7-29.

Landa, J.M., J. Echano, X. Etxebarria, and E. Garro. 2014. Reinserción y personas presas de ETA: análisis jurídico de su estado actual y orientaciones de futuro.

http://www.jmlanda.com/images/cajon-de sastre/1_Informe2014_Reinsercionypresos_CAST.pdf Lazare, A. 2004. On Apology. Oxford: Oxford University Press. Llewellyn, J., and D.Philpott, eds. 2014. Restorative Justice, Reconciliation, and Peacebuilding. Oxford: Oxford University Press. 
Lundy, P. and M. McGovern. 2008. “'Whose Justice?’ Rethinking Transitional Justice from the Bottom Up.” Journal of Law and Society 35(2): 265-292.

Maier, C. 2003. “Overcoming the Past? Narrative and Negotiation, Remembering and Reparation: Issues at the Interface of History and the Law.” In Politics and the past, edited by J. Torpey, 295-304. Oxford: Rowman \& Littlefield Publishers.

Marshall, C. 2007. Terrorism, Religious Violence and Restorative Justice. In Handbook of Restorative Justice, edited by G. Johnstone and D. Van Ness, 372-394. Cullompton: Willan Publishing.

Martinez, I. C. 2012. “Ordóñez a Lasarte: ‘Se lo dije, quien te tendría que perdonar está muerto"”. El País, June 22.

http://politica.elpais.com/politica/2012/06/22/actualidad/1340391988_334894.html

McEvoy, K. 2001. Paramilitary Imprisonment in Northern Ireland. Resistance, Management, and Release. Oxford: Oxford University Press.

Morán, U. 2012. “Deusto debate sobre el papel de la justicia para la convivencia en Euskadi.” El Pais, June 9. https://elpais.com/ccaa/2012/06/08/paisvasco/1339183282 734360.html

Munarriz, F. (2012). El tiempo de las luces. Entrevista con Arnaldo Otegi. Bilbao: Baigorri Argitaletxea, S.L.

Naiz. 2015. “Fernández Díaz descarta la justicia transicional que permitiese avanzar en la paz de Euskal Herria.” September 30.

http://www.naiz.eus/eu/actualidad/noticia/20150930/fernandez-diaz-afirma-que-la-unicajusticia-valida-para-el-conflicto-es-la-de-la-audiencia-nacional 
Ormazabal Elola, S. 2012. Intentos dados en la historia reciente y pasos a dar en el futuro. http://www.vientosur.info/IMG/pdf/Intentos_y_pasos_dados_Sabino_Ormazabal.pdf

Ormazabal, M. 2018. “Zoido: ‘El Gobiemo trabajará hasta que el último de los etarras se arrepienta”. El País, January 27.

https://politica.elpais.com/politica/2018/01/27/actualidad/1517056917_357997.html

Ormazabal, M., and A.Díez. 2018. El Gobiemo avisa de que “ETA no tendrá jamás ninguna contrapartida”. El País, April 21.

https://elpais.com/politica/2018/04/20/actualidad/1524204154_291456.html

Pascual Rodríguez, E., ed. 2013. Los ojos del otro. Encuentros restaurativos entre victimas y ex-miembros de ETA. Santander: Sal Terrae.

Pavlich, G. 2005. Governing Paradoxes of Restorative Justice. London: Glasshouse Press.

Pemberton, A. 2014. “Terrorism, Forgiveness and Restorative Justice.” Oñati Socio-Legal Series 4(3): 369-389.

Pereira, A. 2017. “Preventing or Repairing the Rupture: A Restorative Justice Approach to Individual Radicalisation”. Paper presented at the International Institute for Restorative Practices (IIRP) Europe Conference 9-10 May 2017. Dublin.

https://www.iirp.edu/images/pdf/wvnj_A_restorative_justice_approach_to_radicalisation.pdf

Reunión de Asociaciones y Fundaciones de Víctimas del Terrorismo. 2010. Documento de bases: principios rectores para un modelo de fin de ETA sin impunidad.

http://www.fundacionvt.org/images/fvt/documentos/DOCUMENTO-DE-BASES-PARAUNMODELO-DE-FIN-DE-ETA-SIN-IMPUNIDAD.pdf 
Rios, P. 2014. "Basque Country. Experiences of the Social Forum to Invigorate Peace”. Accord. 25:40-3.

Ríos Martín, J.C. 2013. “El encuentro personal entre quienes asesinaron perteneciendo a ETA y quienes sufrieron el horror injustificado. Descripción, análisis y reflexión”. In Los ojos del otro. Encuentros restaurativos entre victimas y exmiembros de ETA, edited by E. Pascual Rodríguez, 179-228. Santander: Sal Terrae.

Rivas, J. 2012. “27 víctimas trabajan en secreto por la paz.” El País, June 16. http://ccaa.elpais.com/ccaa/2012/06/16/paisvasco/1339850740_524030.html

Rubalcaba, A. 2018. “Sí, es el relato”. El País, May 2.

https://elpais.com/elpais/2018/04/25/opinion/1524669888_905336.html

Sainz, J. 2012. “Instituciones, víctimas y la izquierda abertzale debaten sobre la justicia en paz”. El Diario Vasco, June9.

http://www.diariovasco.com/v/20120609/politica/instituciones-victimas-izquierda-abertzale20120609.html

Sainz, J. 2016. "Errenteria, el laboratorio de la convivencia”. El Diario Vasco, March 31. http://www.diariovasco.com/politica/201603/31/errenteria-laboratorio-convivencia$\underline{201603310648 . h t m l}$

Salas , D. 2015. “How to Fight Terrorism Democratically?” Restorative Justice: an International Journal 3(2): 291-4.

San Miguel, M. 2016. “El valor de lo sensible.” El País, June 7. https://politica.elpais.com/politica/2016/07/30/actualidad/1469906209_076720.html 
Segovia, M. 2013. “Los etarras arrepentidos Guisasola y Alza se unen a Mintegi y Urizar en el homenaje a Joseba Goikoetxea.” El Mundo, November 22. http://www.elmundo.es/paisvasco/2013/11/22/528f360663fd3dc00f8b456a.html

Segovia Bernabé, J.L. 2013. “Actitudes para facilitar encuentros restaurativos con las personas que pertenecieron a ETA.” In Los ojos del otro. Encuentros restaurativos entre victimas y ex-miembros de ETA, edited by E. Pascual Rodríguez, 143-178. Santander: Sal Terrae.

Shirlow, P., and K. McEvoy. 2008. Beyond the Wire. Former Prisoners and Conflict Transformation in Northern Ireland. London: Pluto.

Sluka, J. 2008. “Terrorism and taboo: an anthropological perspective on political violence against civilians.” Critical Studies on Terrorism 1(2):167-183.

Sola, R. 2012a. “Víctimas de ambos lados presentan una reflexión compartida.” Naiz, June 16. http://www.naiz.eus/actualidad/noticia/20120616/victimas-de-ambos-ladospresentan-una$\underline{\text { reflexion-compartida-de-cinco-anos }}$

Sola, R. 2012b. “Euskal Memoria refiere más de 9.600 casos de tortura en los últimos 50 años.” Naiz, November 30. https://www.naiz.eus/eu/actualidad/noticia/20121130/euskalmemoria-refiere-mas-de-9-600-casos-de-tortura-en-los-ultimos-50-anos

Sola, R. 2015. “Azpeitia desnuda sufrimientos para tejer convivencia.” Naiz, April 23. https://www.naiz.eus/en/hemeroteca/gara/editions/2015-04-23/hemeroteca_articles/azpeitiadesnuda-sufrimientos-para-tejer-convivencia

Staiger, I. 2010. “Restorative Justice and Victims of Terrorism”. In Assisting Victims of Terrorism: Towards a European Standard of Justice, edited by R. Letschert, I. Staiger and A. Pemberton, 267-337. London, New York: Springer. 
Sullivan, D. and Tifft, L. 2006. Introduction : the Healing Dimension of Restorative Justice: a One-world Body. In Handbook of Restorative Justice : a Global Perspective, edited by D. Sullivan and L. Tifft, 1-16. London: Routledge.

Tavuchis, N. 1991. Mea Culpa. A Sociology of Apology and Reconciliation. Stanford: Stanford University Press.

Terradillos, A. (2016). Vivir después de Matar. Madrid: La Esfera de los Libros.

Todorov, T. 2009. “Memory as a Remedy for Evil.” Journal of International Criminal Justice 7(3): 447-62.

The Guardian. 2018. "Eta admitted to two new attacks in last missive before dissolving”. November 6. https://www.theguardian.com/world/2018/nov/06/etaadmits-to-two-new-attacks-in-final-missive-before-dissolving Torpey, J. 2003. “Politics and the Past.” In Politics and the Past, edited by J. Torpey, 1-26. Oxford: Rowman \& Littlefield Publishers.

Unzueta Kareaga, H. 2016. Nanclares vis a vis. Cara a cara con la disidencia de ETA. Donostia: EREIN.

Urkijo Azkarate, T. \& Gallizo Llamas, M. 2013. “Epílogo.” In Los ojos del otro. Encuentros restaurativos entre victimas y ex-miembros de ETA, edited by E. Pascual Rodríguez, 321324. Santander: Sal Terrae.

Val, N. 2016. “Los presos de ETA llaman “traidor” a Otegi: prometió amnistía para todos y ahora da marcha atrás.” OKDiario, March 8. https://okdiario.com/espana/2016/03/08/lospresos-de-eta-llaman-traidor-a-otegi-prometio-amnistia-para-todos-y-ahora-da-marcha-atras$\underline{84776}$ 
Varona, G. 2013. “The Meaning of Impunity: What Do Victims, Offenders and Society Think of Restorative Encounters in the Context of ETA Terrorism in Spain?” Restorative Justice: An International Journal 1(2): 215-243.

Varona, G. 2014. “ETA Terrorism Victims’ Experience with Restorative Encounters in Spain.” In Justice for Victims: Perspectives on Rights, Transition and Reconciliation, edited by I. Vanfraechem, A. Pemberton, and F.M.Ndahinda, 322-354. Oxon: Routledge.

Ventura, B. 2012. “La 'Vía Nanclares' explicada en diez preguntas.” El diario, May 15. http://www.eldiario.es/zonacritica/Via-Nanclares-explicada-preguntas_6_4959511.html

VOMA. 2001. A Restorative Response to Terrorism. http://c.ymcdn.com/sites/nafcm.siteym.com/resource/resmgr/Research/Restorative_Response_to_Terr.pdf

Walgrave, L. 2015. “Domestic Terrorism: a Challenge for Restorative Justice.” Restorative Justice: An International Journal 3(2): 282-290.

Walker, M. U. 2006. “Restorative Justice and Reparation.” Journal of Social Philosophy 37(3): 377-395.

White, I. 2003. "Victim-combatant Dialogue in Northern Ireland.” In Reconciliation after Violent Conflict. A Handbook, edited by D. Bloomfield, T. Barnes, and L. Huyse, 89-96. Stockholm: International IDEA.

Whitfield, T. 2014a. Endgame for ETA. Elusive Peace in the Basque Country. London: Hurst \& co. 
Whitfield, T. 2014b. 'Ending ETA: Defeat or a Peace Process?'. World Politics Review. https://www.worldpoliticsreview.com/articles/13498/ending-eta-defeat-or-a-peace-process Woodworth, P. 2014. “Is Low-level Terrorism Preferable to a Peaceful Campaign for Basque Sovereignty?” Irish Times, July 14. http://www.irishtimes.com/culture/books/islow-level-terrorism-preferrable-to-a-peacefulcampaign-for-basque-sovereignty-1.1861860

Woolford, A., and R.S. Ratner. 2008. Informal Reckonings. Conflict Resolution in Mediation, Restorative Justice and Reparations. Oxon: Routledge-Cavendish.

Wright, M. 1996. Justice for Victims and Offenders: A Restorative Response to Crime. Winchester: Waterside Press.

Zaldua, B. 2012. “Barrena propone «justicia transicional» y su intervención es agradecida por la hija de Lluch.” Naiz, November 22.

http://www.naiz.eus/eu/actualidad/noticia/20121122/la-izquierda-abertzale-asume-sin-temorel-dolor-causado-a-las-victimas

Zarzalejos, J. 2014. “La Derrota y Su Relato”. Cuadernos de Pensamiento Político, 41, 1531. http://www.fundacionfaes.org/file_upload/publication/pdf/20140113131858la_derrota_y_su_ relato.pdf

Zehr, H. 1990. Changing Lenses: A New Focus for Crime and Justice. Scottdale, PA: Herald Press.

Zernova, M. 2007. Restorative Justice: Ideals and Realities. Aldershot: Ashgate.

Zernova, M. 2017. "Restorative Justice in the Basque Peace Process: Some Experiments and Their Lessons”. Contemporary Justice Review 20(3): 363-391. 


\section{Zulaika, J. 2009. Terrorism: The Self-Fulfilling Prophecy. Chicago: The University of Chicago Press.}

Zulaika, J. 2018. “The Real and the Bluff: on the Ontology of Terrorism”. In Routledge Handbook of Critical Terrorism Studies, edited by R. Jackson, 39-48. London and New York: Routledge.

Zulaika, J., and W.Douglass. 1996. Terror and Taboo. New York and London: Routledge. Zulaika, J., and I.Murua. 2017. "How Terrorism Ends - and Does Not End: the Basque case”. Critical Studies on Terrorism 10(2): 338-356 .

\footnotetext{
' The numbers of lives lost on both sides are disputed, yet ETA has admitted killing 758 people (The Guardian 2018). Euskal Memoria puts forward a list of 474 victims of the state repression (see Ormazabal Elola (2012) and Whitfield $(2014,283)$ for a critique of this figure).

ii Following the collapse of Rajoy’s government in June 2018, the new Prime Minister Pedro Sánchez announced plans to start transferring ETA prisoners closer to their homes, and in August 2018 the first two prisoners were relocated. These developments were opposed by the Spanish political right and leading victims of terrorism associations who linked the transfers to the support of Basque nationalists for the no-confidence vote that brought Pedro Sánchez to power. In response, the new government has provided assurances that the prisoners will be relocated on an 'individualised' basis, and there will be no progressions to the second or third 'grade' regime allowing prisoners penitentiary benefits, let alone early releases. By December 2018, thirteen prisoners
} were brought closer to their homes and three others were classified in the 'third' grade regime.

iii The adherence to the 'conflict' narrative embodied in ETA's apology produced controversy, as it made a distinction between 'all victims' and the victims 'with no responsibility in the conflict'. While ETA said 'we are truly sorry' to all its victims, it only asked for forgiveness those 'with no responsibility in the conflict' (Ormazabal and Díez 2018). ETA’s apology was immediately dismissed by the Association of Victims of Terrorism on the grounds that ETA used its apology to 'dilute its real responsibility, justify its use of violence to impose its totalitarian project and manipulate history’. 